\title{
Analysing partition: Definition, classification and explanation
}

\author{
Brendan O'Leary*
}

Lauder Professor of Political Science, University of Pennsylvania, Penn Program in Ethnic Conflict, 3819-33 Chestnut Street, Philadelphia, PA 19104, USA

\begin{abstract}
Political partitions should be carefully distinguished from secessions, de-colonizations and disengagements - though they may accompany these phenomena. Political partitions involve a fresh cut, an at least partially novel border, ripped through at least one national community's homeland. Partitions of national and multinational polities may be distinguished, as may external and internal partitions. External partitions have been rarer than suggested in conventional accounts, and explanations of their occurrence are evaluated, and recommendations are made that their rarity should persist.
\end{abstract}

(C) 2007 Elsevier Ltd. All rights reserved.

Keywords: Partition; Secession; British empire; Ireland; Palestine; India-Pakistan; Borders; Homelands; Cyprus; Kurdistan-Iraq

\section{Wording matters: parsing partition}

partition n. \& v.-n. 1. division into parts, esp. Polit. of a country with separate areas of government. 2. a structure dividing a space into two parts, esp. a light interior wall. v.tr. 1. divide into parts. 2. (foll. by off) separate (part of a room, etc.) with a partition. ${ }^{\square}$ partitioned adj. partitioner n. partitionist n. [ME f. OF f. L partitio -onis (as PARTITE)] (Concise Oxford Dictionary, 1990: 868).

partition n. (15c) 1: the action of parting: the state of being parted: DIVISION, 2: something that divides: esp. an interior dividing wall, 3: one of the parts or sections of a whole.

\footnotetext{
* Corresponding author. Tel.: +1 2679180686.

E-mail address: boleary@sas.upenn.edu
} 
partition vt (1653) 1a: to divide into parts or shares b: to divide (as a country) into two or more territorial units having separate political status, 2: to separate or divide by partition (as a wall)-often used with off partitioner $n$

partitionist n. (ca. 1900): an advocate of political partition. (Merriam-Webster's Collegiate Dictionary, 11th ed., 2003: 904).

The standard dictionaries of English suggest that partition and division are synonyms. Partition, in a general sense, is the division of an entity into parts. It may be analytical; a mathematician partitioning one side of an expression to develop a proof divides nothing in the physical world, even though the deductions may be recorded in writing. But partition may be actual; something that exists is divided; independently of what observers think, a unified entity is divided into parts, as when a butcher dismembers a sheep's body. Partition may also be subjective, defined by the beholder: one observer complains of the division of an entity into parts, but another may deny that it was a unified entity.

In politics a partition has generally been considered as an objective description. A previously unified territorial entity is divided into two or more parts, which may be marked with borders, codified in new maps, and operationalized, for example, in demarcated lines, perhaps accompanied by fences, walls, paint or barbed wire, or punctuated with official posts where passes or passports may be demanded. But reactions to a political partition are always subjective, though in a systematic manner-there will be proponents, opponents and the indifferent, who are always with us. And what is at stake for opponents (and sometimes proponents) is their respective "homelands". 1

Recent policy debates in the United States over the future of Iraq have identified proponents of "hard partition", that is, those who advocate forming three new sovereign and independent states in Iraq, usually involving the creation of 'the South', 'the Center' and 'Kurdistan', as modifications of the old Ottoman vilayets of Basra, Baghdad and Mosul. In my view, "soft partition" is, by contrast, a misleading notion. It is used to describe proposals that wish to deepen regionalization within Iraq, that is, to enable existing governorates (provinces) to aggregate to form highly autonomous regions, along the model of the Kurdistan region, proposals which are compatible with Iraq's constitution of 2005, and do not involve creating either independent states or deliberately creating fresh borders cut across any community's homeland. This evaluation implies that there is a correct and useful way to define and code partition, and that there are more capacious and misleading ways to use the term, which should be avoided. That is indeed what is suggested in this article. ${ }^{2}$

To begin, let us distinguish secession from partition. Let me suggest that the notions of "unfastening" and "tearing" usefully metaphorically capture the two major types of political division of territory. To unfasten is to separate using a previously organized mechanism, that is along a previous ordered line of division; the mechanism takes apart what was previously separately constructed and does so along the original line of unification. "Unzipping" is most efficient unfastening. Political unfastening, we might suggest, unwinds time to a previous

\footnotetext{
${ }^{1}$ No attempt will be made here to evaluate or explain the mass and elite psychology of "homelands". For contrasting efforts in using homelands as "independent" and "dependent" variables see Connor (1986) and Esman (1985) compared with Brubaker (1996). For an overview treatment see Yiftachel (2001), and compare with Voltaire (1999, 1764). For a discussion of conflicting 'homeland myths' in post-communist Russia see Tolz (1998).

${ }^{2}$ In a separate article (O'Leary, 2007), I address the prescriptive arguments of partitionists and anti-partitionists, engaging in particular with the partitionist arguments of Kaufmann (1996a, 1996b, 1998).
} 
territorial order, when there was no unity. Such unfastening is the goal of secessionists. Tearing, by contrast with unfastening (or unzipping), involves a fresh cut, a rip, a gash, a slash; only with remarkable luck or skill will it resemble an unfastening. Tearing is what happens in a political partition, especially in the eyes and voices of those who oppose it. The blood and guts spilled before, in, and after partition are not dulled by any anesthetic. These metaphors underpin the claim that a political partition should be defined as a fresh border cut through at least one community's national homeland, creating at least two separate political units under different sovereigns or authorities (adapted from O'Leary, 2001: 54). ${ }^{3}$ The ostensible purpose of a political partition, its formal justification, is that it will regulate, that is reduce or resolve a national, ethnic or communal conflict.

The difference between "cutting afresh" and "unfastening" does not convey all the attributes of partition or secession, or all their typical differences. But consider how partitions are treated as "tears" by their opponents. What are protested are the freshness, the novelty, the brutality, and the artificiality of dividing a "national" territory, a homeland, and a province. The partition of Ireland and of Ulster were condemned in this way, by Irish nationalists and especially by those Ulster unionists whose counties were not left in the UK. The opponents of partition in India and Ireland used medical metaphors: "an operation, an amputation, a dismemberment or a vivisection" (Chatterji, 1999: 168), or suggested that it would be performed on a "dissecting table" (Connolly, 1975).

Such complaints are modern. They take the nation-state and its national territory for granted. Pre-modern dynasties, by contrast, treated lands as real estate, and their peoples as herds of human capital; thus, in feudal and patrimonial regimes, "partition" had no political meaning outside of estate law; and land divisions were not the subject of debates over their national public legitimacy. The "Partitions of Poland" (1772, 1793 and 1795) that terminated in the removal of the ancient kingdom from the world's maps changed terminological history. The tripartite carve-up of Poland between the Romanovs, the Hohenzollerns and the Habsburgs generated the pejorative associations of partition (Mansergh, 1997: 32-33). ${ }^{4}$ The denunciation of Catherine, Frederick and Marie Therese (the only one of the three not deemed "Great") foretold the legitimacy of nationalist presumptions: to each nation, there is a homeland in which it is entitled to govern itself. It also foretold the illegitimacy of imperialist acquisition and of territorial conquest. The modern norm of respecting the territorial integrity of states in part flows from the acceptance of both nationalist and democratic ideas and practices in the international order, and their respective rejections of the legitimacy of conquest (Zacher, 2001). It is against the norm of respect for the territorial integrity of states that proposals to partition independent states are now judged unlawful and wrong. (It hardly needs remarking that particular nationalities may

\footnotetext{
${ }^{3}$ This definition generally resonates with those who have opposed partitions, especially its victims, but that is not why it is defended. The proposed definition is not the claim that ordinary usage is the correct meaning, though significant users implicitly employ it the way I suggest it should be used in the social and historical sciences. Contrary to the linguistic philosophers, who fetishized ordinary usage, it is sensible to improve existing terms - as Ernest Gellner (1979) argued. I attempt just that; not from some misguided authoritarian effort to impose an (arbitrary) version of standard English, but to aid empirical explanation and political evaluation of the same subject, and to avoid confusing the concept of a political partition with other concepts (such as secession, de-colonization, and federalization by consent).

${ }^{4}$ Some claim that the partitions of Poland helped to create a popular Polish identity where one had not previously existed, except among the aristocracy (see Kaplan, 1972; Lukowski, 1998). Rousseau's The Government of Poland (1985 [1770]) was commissioned, in vain, to counsel on how build a Polish national consciousness that would enable Poland to resist its consumption by its rivals.
} 
not regard the territorial integrity of existing states as respecting the territories of their homelands).

As a result of the diffusion of democratic and nationalist understandings of self-determination in the 20th century the treatment of political partition as illegitimate "tearing" became standard, outside the distinctive circles of British imperial statecraft, and apologies for that craft. Today, there are some limited signs of empathetic recrudescence in favor of partition among those who would advise on US global engagements. But, to be fair, most partitionists propose this policy in particular locations, such as the Balkans or Iraq, as political triage. If triage is the allocation of treatment to patients to maximize the number of survivors, amputation is individual-level triage, the cutting off of rotten or bleeding limbs that might otherwise kill the patient; in political partitions, the hope of the proponents is that both the rump and the amputated limb will do better without each other.

Partition, to finish these metaphorical and medical classifications, is a violation of the integrity of the body politic for its opponents. But for its proponents, it is essential crisis-survival management, with the remarkable claim that after surgery all the entities will be better off. The promise is that partition can separate Siamese twins. Both sides accept that a "fresh cut" is involved; the difference is that the proponents hope for surgical precision, which opponents know is not possible.

This account of the metaphors that surround partition may be met with the observation that secessions are proposed, and opposed, with the same analogical battery-of cuts, tears, slashes and rips. Granted, political argument is not unremittingly tidy, and metaphors from one type of action may be deliberately applied in another, because that may be useful propaganda. But in fact secession is promoted and opposed as "unfastening", dividing along a previously established line of division. Secessionists usually have an established claim to a unit, either in recent or older history. Opponents of secession usually forget that the secessionist unit historically joined the existing system, and were therefore not always "part of us". Proponents of secession remember a prior territorial status, and insist that past marriage-whether performed for love, under the shotgun, for dynastic politics, or under coercion, or induced by bribery-implies a right of divorce.

Partition, on this account, involves the truncation of at least one prior unit, even if it involves the extension of others. The partition of Germany after World War II included its division into two units, West and East, the transfer of prior German national territory to France, Poland and the USSR, and the return of recently "obtained" German national territory in the Sudetenland, and elsewhere. ${ }^{5}$ The extension of prior states or provinces is best known as "annexation" - though it may be protested as "partition" by the loser(s). Partition involves some new lines on the map, either externally (on the edges of a sovereign state) or internally (within such a state). There is some novel part of the new line(s) of demarcation. Though partitions may be glossed with historical fictions, not all their edges are old. Six such fresh cuts may be given as examples here.

1. The partition of Ireland (1920). The Government of Ireland Act of 1920 was executed on county lines, which did not sharply or otherwise demarcate national, ethnic or religious boundaries, and which did not, except in the case of the southern borders of county Down and Armagh, correspond with the border of the historic province of Ulster, which in 1920

\footnotetext{
${ }^{5}$ Austria, which had fastened itself to Germany in 1938, restored itself (with Allied help) within its pre-Anschluss boundaries; it exercised an assisted secession.
} 
had, in any case, no legislative, judicial or executive significance (McGarry \& O'Leary, 1995: chap. 1). The partition was a novel border; it was a fresh cut across both Ulster and Ireland.

2. The partition of Hungary (1920). The treaty of Trianon (1920) partitioned Hungary in the course of "dissolving" the Hungarian component of the Austro-Hungarian Empire. In doing so, it neither respected Hungary's borders within the old empire, nor did it conform to any prior political or administrative demarcation of Hungary.

3. The partition of Kurdistan (1920-1923). The Treaty of Sèvres (1920) proposed the formation of an independent Kurdistan, and gave the overwhelmingly Kurdish Ottoman vilayat of Mosul the right to join it, but the Treaty of Lausanne (1923), which ratified Kemal Ataturk's military victories, extinguished this nascent Kurdistan, which was partitioned between the novel entities of British mandate Iraq, French mandate Syria, and Kemalist Turkey.

4. The partition of India (1947). The partition of India is also known as the partition of Punjab and Bengal, and was executed by Radcliffe's commission. It created a novel border separating India from two entities, West and East Pakistan, and the new lines did not restore old Mughal jurisdictions. Radcliffe's "award" during the partition of Bengal in 1947 conceded the argument of the Indian National Congress (1947) that thanas, the smallest units for which census figures had been published, were the most acceptable units around which to organize partition (Chatterji, 1999: 191). But these thanas were police stations, or criminal law jurisdictions; they did not define the edges of Bengal's national or ethnic or religious homeland(s) or communities, nor were they units of self-government. And, in the interests of contiguity, Radcliffe's award did not (and could not) always award thanas with the relevant Hindu or Muslim majority to their appropriate state.

5. The partition plans for Palestine (1937 and 1948). Neither the Peel Commission of 1937, nor the partition proposals of the United Nations of 1947, radically different from one another, respected prior Ottoman or British Mandate administrative boundaries.

6. The partition of Cyprus (1974). Executed by the Turkish army, this partition created a novel political border, one that had not existed under British or Ottoman rule, or within independent Cyprus.

These illustrations support the understanding that at least these partitions were fresh cuts. But are these illustrations merely anecdotal propaganda? Why should such care be taken over the definition of partition? Why should we not work with a much broader definition of partition, such as the division of an entity into two or more units having separate political status? The answer proposed here is that the coding of cases of partition necessarily affects evaluations of its frequency, of its explanations, and of its justifications. Here my focus is on frequency and explanations; I address justifications elsewhere (O'Leary, 2007).

\section{Defining partition}

\section{Partition in recent scholarship}

Consider the dissensus, and slight touch of carelessness, on how to define partition among otherwise industrious and very intelligent scholars. We may begin with a recent quantitative analysis by Sambanis (2000). It is a very interesting work, and many of its arguments against partitions are persuasive. But, by my account, it conflates partition and secession, which renders its assessment suspect. The following are just some of Sambanis' more overtly controversial inclusions in the category of late 20th century partitions: Eritrea-Ethiopia, Georgia (Abkhazia 
and South Ossetia), Russia-Chechnya, Somalia-Somaliland, Yugoslavia-Croatia (1991-1995), and China-Taiwan. In most of these cases, secessions were attempted, or took place, within existing political borders which had previously recognized the relevant national homelands (Eritrea, Abkhazia, South Ossetia, Chechnya, and Croatia), ${ }^{6}$ or around a previous and recent political boundary (Somaliland). ${ }^{7}$ The Croatian secession of 1991 was militarily contested, but there was no attempted partition until Serbian irregulars backed by Belgrade held the Krajina (eastern Croatia). ${ }^{8}$ In the last of these instances, China-Taiwan, the present situation flows from an unresolved civil war within a nation, in which until recently the governments of both units claimed to be the government of all of China, and ardently proclaimed their desire to see its reunification. "Mainland" China is recognized by the United Nations, whereas Taiwan is not - and Taiwan openly debates whether to declare independence from China, which suggests that, on its own understanding, it has not yet seceded. Rival Chinese armies, not foreigners, carried out the division of China (though the Chinese civil war was aggravated by Japanese intervention, and the maintenance of the division was entrenched by US support for Taiwan). It is not clear that Taiwan has seceded from China, or, legally, that China has been partitioned, though plainly all may agree that there is a de facto partition. This brief review of these five cases in Sambanis's data set suggests, contra Sambanis, that it is historically and analytically useful to distinguish secession and partition.

Sambanis' focus is on a data set of all civil wars since 1944, in which he defines partition as a "war outcome that involves both border adjustment and demographic changes" (Sambanis, 2000: 7). ${ }^{9}$ This seems too broad. The reference to "border adjustment" assimilates secessions and partitions. A partition on the account advocated here involves a border adjustment, because there must be a fresh, novel border, but a secession just involves a border transformation, that is, the breakup of the prior sovereign entity and the conversion of the previously agreed (internal) border to a sovereign demarcation. Sambanis' definition also requires "demographic changes" and that the new border is the outcome of a war. It is reasonable to predict that partitions cause demographic shifts, and that both demographic and border shifts occur after wars, but these possible consequences should not be part of the definition. It excludes the possibility of pre-emptive partitions, motivated to prevent war, ${ }^{10}$ and the theoretical possibility that partitions might be peaceful.

\footnotetext{
${ }^{6}$ Eritrea is multi-religious and multi-ethnic, as is Ethiopia, but Eritrea had a previous existence, and borders, as an Italian colony - and as a federated entity in an Ethiopian federation that did not materialize as promised to Eritrea by the United Nations. For these reasons, the Organization of African Unity recognized Eritrea's secession from Ethiopia as a special case, or rather as a non-exception to its commitment to defending the colonial boundaries imposed on Africa. Ethiopia recognized Eritrea's right to secede, and overwhelming endorsement in a popular referendum then occurred. Until the recent border war between the two states (over a largely unpopulated area) there had been no dispute over the borders of the Eritrean unit.

${ }^{7}$ Somaliland's secession has not been internationally recognized but Sambanis counts it. Somaliland has defined its borders as those of the former British Somaliland, and is widely recognized as the homeland of one of the Somali clans maltreated by the regime of Mohammed Siyad Barre. Some Somalilander elites reject even the idea of confederation with the rest of the former Somalia. For a defense of the Somalilanders, see Drysdale (2000). The Somali homelands were partitioned in the 19th and early 20th centuries by the empires of Abyssinia, Britain, France and Italy.

${ }^{8}$ This attempted partition of Croatia was subsequently rebuffed. Notoriously, Croatian elites conspired with Slobodan Milosevic to partition Bosnia-Herzegovina, a plot that ultimately was thwarted (see Hoare, 1997).

${ }^{9}$ This and subsequent page references are to the pdf version of this article on the world Wide Web.

${ }^{10}$ Sambanis (2000: 44 n. 8) defends his approach (i) by implying that all partition theorists do not discuss partitions as a preventative measure before war occurs - an odd idea; and (ii) by arguing that his main research question is "war recurrence". But his peculiar definition of partition does not test whether partition proper leads to war recurrence.
} 
Sambanis correctly observes that other scholars use secession and partition interchangeably. Some political geographers do. Peter Taylor, for example, treats the dismantling of the USSR into its constituent parts as a partition. Whereas on the approach advocated here, the breakup, division, or divorce, of an empire or state (of a confederation, or of a federation, or of a union under a common crown) around its existing internal jurisdictions may involve more than one secession, but it does not constitute a partition unless there is at least one fresh cut. Taylor's approach is consistent with his definition of partition as "the division of a state into two or more territories which constitute new states", and of secession as "the act of separating a territory from a state" (Taylor, 1993: 173, 333, 335), and political scientists generally proceed as he does. ${ }^{11}$ So Sambanis is right. There is a lot of conflation of partitions and secessions, and not only among academics. Arguably that shared confusion needs to be cleared up.

Horowitz (1985) and Heraclides (1991) treat matters differently, though Sambanis thinks their views are close to his. Horowitz defines partitions as "radical surgery ... separating the antagonists" (1985: 588-589). This, implicitly, is consistent with the definitional approach advocated here. Horowitz, however, draws no sharp distinction between secession and partition, especially when discussing partitions, though it is telling that his case materials treat partitions in different passages from his treatment of secessions (1985: 588-592, 229-281). Heraclides (1991: 24), by contrast, defines partition as "the formation of two or more states by mutual consent", and a secession as "an abrupt unilateral move to independence on the part of a region that is a metropolitan territory of a sovereign independent state" that is "opposed by the Center" (Heraclides, 1991: 1). He declares that the borderline "can often be blurred" between secession, which he (wrongly) describes as unacceptable in international law, and partition, which he describes as acceptable in international law (which is true only if partitions correspond with his definition in which consent is required). ${ }^{12}$ Heraclides' position implies that another concept, other than partition, is required for imposed divisions in the formation of the borders of new states or territories, because his stipulation makes all partitions consensual.

Heraclides is right that a secession can be accompanied by a partition, but he is wrong, I think, in the example that he gives, namely Norway's peaceful secession from Sweden (discussed by Young, 1994; and see Lindgren, 1959). The Swedes did not regard Norway's departure within its existing home rule borders under the then-common crown as a partition of Sweden, a conviction obviously shared by the exiting Norwegians, since a mere 184 of them voted against the formation of an independent kingdom. The useful element in Heraclides' definition of secession is its insistence that the entity that wishes to secede is part of the "metropolitan" center. It is his way of saying that secession is the act of a territorial entity that has equal status with the rest of the center, whereas a colony engages in liberation when it exits an empire, a thought to which I shall return. But, pace Heraclides, secessions and partitions

\footnotetext{
${ }^{11}$ The breakup of Czechoslovakia has been misdescribed as a partition, even though the boundaries of the two new sovereign units were not changed (no fresh cut) (O'Leary \& McGarry, 1995: 255). For another example of this error, see Lake and Rothchild (1998: 11). The authors attribute a "mutually agreeable separation" to the two ethnic groups themselves, when the mass publics of each nation in fact opposed a breakup. An excellent guide to the breakup of Czechoslovakia, a double secession, driven by Czech elites interested in "downsizing" or dereliction, and by Slovak elites who overplayed their hand, can be found in Innes (2001).

${ }^{12}$ Under recent international law a decolonizing empire may not partition a colony without a process of consent (Conras, 1975). A United Nations Declaration of 1960, on the granting of independence to colonial countries and peoples, declared that any attempt at the partial or total disruption of the national unity and territorial integrity of a country was incompatible with the UN Charter.
} 
are distinct, even if both can occur during the same conjuncture. It is not just coherent to claim that Ireland was partitioned in 1920, and that Ireland seceded from the UK in 1921, and that Northern Ireland seceded from the Irish Free State under the terms of the Anglo-Irish Treaty of 1921. It is in fact and in law what happened.

Kaufmann (1998) distinguishes partitions from secessions, but in a curious manner. He defines secessions as unilateral breaks from a state, whereas partitions are either "jointly decided or imposed". This is a fairly clear distinction, but it forecloses the possibility that a secession can be agreed. Do Norway's departure from Sweden, Singapore's departure from Malaysia, and Slovakia's departure from Czechoslovakia become partitions because there was an agreement among political elites? These three cases are usually and better understood as peaceful secessions (though some argue that Malaysia expelled Singapore from its federation; see the discussion in Young, 1994). In the Czech case, a double secession occurred from the previously shared federation (Innes, 2001). Perhaps Kaufmann is too much influenced by the US historical experience in which attempted secession was very bloody.

\section{In defense of the fresh cut distinction}

The insistence that a "fresh cut" is an essential component in a political "partition" has an empirical rationale. It defines the notion precisely, differentiates it from adjacent phenomena, and explains better the intellectual and mass subjective responses to "partition". One frequent objection to this proposed definition is that it biases, deliberately or otherwise, normative argument in favor of secessionists. The latter have their units, which makes their enterprises easier, and perhaps more painless. But, it may be said, what about groups that do not have recognized units? Some groups may not have had recent authorized self-government of any kind in administrative units that roughly approximate their homelands. Usually this will be because they have been historically crushed by others and subsequently abused-the position of most Kurds in much of the 20th century.

This example aids the clarification of terms. Kurdish nationalists are unable to secede from Iraq (or Turkey, or Syria or Iran) before they establish a Kurdistan unit. There is now a Kurdistan Region in Iraq and a Kurdistan Province in Iran, both of which make secession possible, though, of course, not necessary. A Kurdistan in Turkey or Syria would have to be establishedthrough a liberation struggle or a political agreement or both-before a secession could be even entertained. Only a putative equal with a recognized territory secedes; by contrast, an unequal struggles for liberation. Secessionists have territories; liberationists, by contrast, must establish their territory. They may base such claims on earlier historic jurisdictions, in which case their movement will resemble a secession. This distinction between secessionists and liberationists implies no bias, and conforms to much political language. But what if the liberationists take territory in which others' nationals are resident? Does that involve a partition? Yes, subjectively. If those nationals are living in what they credibly regard as their national territory, within already formally established boundaries, they will argue that others' national liberation will take place through the partition of their homeland.

So, in short, partition may accompany both secession and national liberation, but it is conceptually distinct. Partition should be distinguished both from secession, and from the recognition of a secession by a political center. This distinction is partly a matter of agency. Empires or states (or provinces in federations) execute partitions. Secession, by contrast, is an action of regions, or provinces, or member-states of a federation or union state that may, reluctantly, be accepted by a political center (states only have a presumptive right of secession within confederations). By 
contrast, partition is something states do, that they can execute on a seceding region, against a national liberation movement, or in the course of "down-sizing". ${ }^{13}$ The latter is also executed by a political center. It is the quitting of a territory. If downsizing leaves prior provincial borders untouched, there is no partition. It is decolonization (if there is an organized transfer of authority), or dereliction (if there is not).

To sum up, partitions are not best understood as the same phenomena as secessions, national liberation movements, or the downsizing of regimes (whether decolonization or dereliction), though they may accompany each of these phenomena. Partition is best understood politically as something quite specific, and not as every change affecting borders. Partition therefore merits separate description, evaluation, and explanation, as well as assessment of its likely interaction with these adjacent phenomena.

The definitional approach advocated here seeks to capture the commonsensical content of what is at stake in a partition (at least in English), but it does not pretend to settle evaluative argument - surely meritorious in a definition. Evaluation must depend on who is doing the partitioning, for what purposes, and with what likely consequences. The merits of any definition lie in its explanatory usefulness. The claim here is that distinguishing a delimited class of partitions from the broader category of territorial divisions illuminates analysis, explanation, and prescription. This paper focuses on analysis and explanation; another focuses on prescription (O'Leary, 2007).

\section{Classifying partition}

For those in agreement so far, political partitions share an essence: they are fresh border cuts across a national homeland. They are formally intended by their promoters to regulate or resolve national, ethnic or communal conflicts. But they may be distinguished in four ways, by

- whether they partition national or multinational polities;

- whether they are external or internal;

- the agents promoting, supporting and implementing them; and

- the prior political status of the partitioned entities.

\section{National versus multinational partitions}

National partitions divide relatively homogeneous nations in their homelands. Unambiguous examples are the partitions of Germany, Korea and Vietnam at the onset of the cold war. More debatable examples include the partition of Mongolia, Kurdistan and Armenia; here prior unity is contested in historiography and rival collective memories. Another is the division of China and Taiwan, debatable because of the sharp cultural differences between the natives of historic Formosa and the settlers from the losers of the Chinese civil war. National partitions are generally caused by civil wars accompanied by large-scale interstate wars or cold wars or foreign interventions that stabilize the lines of control of the respective regimes. ${ }^{14}$ These partitions give rise to "schizophrenic" entities, both of which claim to be the true embodiment of the nation,

\footnotetext{
${ }^{13}$ For downsizing and strategies designed to eliminate and to manage ethno-national differences, see O'Leary, 2001 and McGarry and O’Leary, 1993.

${ }^{14}$ None of these partitions match Heraclides' idea that a partition must be mutually agreed.
} 
and seek its reunification in their image. National partitions are regarded on both sides of the partition line as abominations, artificial and unsustainable. In Germany, the capitalist liberal democratic west eventually prevailed; in Vietnam, the communist north. National partitions are initially characterized by mutual non-recognition of the respective regimes, though this may give way to rapprochement and coexistence. One entity at least will initially try to fortify and close the border(s), and to subvert the opposing regime, though again this may give way to more open cross-border arrangements. National partitions are preserved if the partition was initially deeply ideological, as it was between the two Vietnams, Koreas, and the Germanys, where the ideologues remain relentless in their respective jurisdictions, and if their continuing division is strongly supported by great or neighboring powers. The USA forcefully blocked the military unification of Korea in the 1950s and of Vietnam before 1972-1975, and the USSR vetoed the reunification of Germany until the Gorbachev era. ${ }^{15}$ Full democratization leads to reunification movements to reverse national partitions, unless separation has endured so long that two nations have emerged (as many analysts wrongly assumed about Germany).

Multinational partitions divide ethnically, religiously, communally or nationally heterogeneous polities. ${ }^{16}$ The partitions of empires, such as the partitions of the Austro-Hungarian and the Ottoman empires after World War I, are exemplary cases where the new divisions cut across homeland boundaries. The deliberate breakup of national or ethnic units within a federation, or a union state, on this understanding, is a national partition for each nationality that is divided. So the CPA's proposal to divide the Kurdistan region by three governorates and not to have a Kurdistan region was regarded by Kurds as a proposal to partition their national territory (again). When the maintenance of heterogeneity within units is the political goal of border designers and redesigners - as was often the case in the drawing of the boundaries of Soviet republics and the jurisdictions beneath them, and as has been true of the military redesigns of Nigeria's federation after the military defeat of Biafra's secession, we may also code such cases as multinational partitions. Here the goal was to partition as many nations as possible. By contrast, redesigning pluralist federations to form internal political borders that correspond with ethno-national homelands or linguistic units are "restorative" border architectures, rather than entirely fresh cuts, especially when executed with consensus. They should not be coded as national partitions.

\section{Internal versus external partitions}

Internal partitions are driven by three strategic goals: control, integration or autonomy. Internal partition to achieve control involves the deliberate use of hierarchical management strategies, to organize one or more ethno-national groups, and to disorganize and dominate others. Gerrymandering and provincial fragmentation deliberately dilute the local political concentration of the dominated ethno-national group(s). Internal partition for integration, by contrast, is the territorial carving out of heterogeneous units of government out of more homogeneous entities, with the intention - through mixing — of diminishing conflicts between national, ethnic or religious communities. This will normally be coded by its opponents as a form of control rather

\footnotetext{
${ }^{15}$ The veto applied after 1952, after the failure of the "Stalin notes" to bring about reunification-historians still dispute the sincerity of this offer, which was rejected outright by Adenauer and the USA.

${ }^{16}$ This argument follows Henderson and Lebow (1974: 433 et seq), who distinguish "divided nations" (Germany, Korea, Vietnam, Mongolia) from "partitioned countries" (Ireland, India, Rwanda-Burundi, and Palestine). I have changed their wording for terminological consistency, and to emphasize that both sets of cases involved partitions of nations, that is, fresh cuts along novel lines for at least one national homeland.
} 
than as integration. Lastly, an internal partition may be organized to promote the autonomy of a particular group that has no previously recognized jurisdiction-which is one interpretation of the formation of Northern Ireland out of historic Ulster. Such internal partitions need lead to no change in the existing external sovereign border of the state (empire or federation or union state) in question. ${ }^{17}$ In the case of the partition of Ireland, one of the aims of the Government of Ireland Act of 1920 was to keep both Irish nationalists and Ulster Unionists within the Union by granting autonomy ("home rule") to both of them. External partitions, by contrast, necessarily involve both the modification of prior homeland jurisdictions, and the attempted or actual transformation of the status of the existing sovereign border. The partition of Hungary is a good example. So are the partitions of India and Cyprus.

\section{Inside versus outside agents of partition}

The agents of partition may be distinguished by whether they are "outsiders" or "insiders". Outsiders include conquerors (imperialists, interventionists and leagues or alliances engaged in temporary occupations) and perhaps international organizations. Sovereign insiders include central governments and local collaborators. Partitions may occur through interactions between outsiders and insiders. ${ }^{18}$ Partitionists of nations, of course, are often outsiders, who want these nations divided for military reasons.

In the cases of national partitions that flow from internal civil wars, it is clear that insiders would fight their civil war to the finish until reunification occurred, or that they would peacefully negotiate their reunification. In a national partition, all insiders, at least initially, regard the partition as temporary. So, unless there is a military stalemate, without outsiders such partitions will not endure. By contrast, the partitionists of plurinational, pluriethnic, plurilingual and

\footnotetext{
${ }^{17}$ The territorial re-division of an existing national homeland by homelanders, for example, the creation of new local government units or new federal territorial jurisdictions, appears to involve fresh cuts, but such divisions are not, on my approach, partitions if they are within the nation's choices of self-government-and irrelevant to the management or resolution of internal national, ethnic or communal conflicts. The homeland may administer its home as its wishes; its internal jurisdictions are not "partitions". So, the division of England into new regions would not be an internal partition if it was agreed by English MPs, both in England as a whole, and within the new regions. If it was imposed against an English majority of MPs (because of Scots and Welsh MPs, and "West Lothian" questions) that would complicate matters. Where internal re-divisions deliberately cut across existing national homelands to disorganize an ethnic or ethno-national community, then it is a form of control. If, by contrast, re-divisions within a multinational state deliberately and consensually realign national homelands with political jurisdictions, then this is an autonomy settlement or federation-building (and will be understood as a restoration of borders, rather than as a fresh cut). Political geographers (for example, Waterman, 1987: 152) tend to label all internal re-divisions as partitions. They refer to partition as an "attribute" in which "a single unit on a map is divided into two or more parts" (Waterman, 1987: 151), and endorse Scruton's definition of partition: "The political division of a territory into autonomous sections, with or without the migration of the peoples resident there, in order to establish two governments" (Scruton, 1982: 345; Waterman, 1987: 155). This definition is coherent, but does not distinguish partition from secession, and requires that the post-partition territories be self-governing (which may not immediately be true of plausible cases, for example in East Bengal after 1948 or the West Bank of the Jordan after 1948 or 1967). Waterman (1984: 100; 1987), however, differentiates partitions from imperial breakups or collapses.

${ }^{18}$ It might seem that by our definition an external partition cannot be proposed or executed by insiders alone, that is by those within the territory that is to be partitioned. That is not right. A national liberation movement, fighting to be free from an empire, may have to carve out its own self-proclaimed national territory, for which it will seek recognition, but might in the process engage in one or more partitions if its liberation struggle leads to fresh jurisdictional cuts across the credibly established homelands of other national communities. In this case, the partitionist is, of course, intent on building a state, that is, to become an outsider.
} 
pluricommunal entities usually include both outsiders and insiders. Outsiders believe, or at least argue, that partition will eliminate (or at least reduce) ethno-national or other identity-based political differences; and they will be supported by at least some insiders who argue the same case. For them, partitions are proposed as long-run resolutions of conflict.

\section{Political status of partitions}

Lastly, we may distinguish the political status of the entities that are partitioned. Here we may differentiate the status of the territories and of their peoples. In external partitions, the territories may be empires or states that have lost wars. In internal partitions, they may be the provinces of union states or federations-entities with equal legal status to other provinces. Within empires, they may be colonies (conquered entities held under direct or indirect rule), and not of equal status to provinces in the imperial core. The peoples in partitioned territories may be citizens or colonial subjects (including migrant workers). They may be nomads or hunter-gatherers, who are not recognized as having any national consciousness, as with the subjects of many of the colonial partitions of Africa.

\section{The comparative paucity of externally imposed multi-national partitions}

The focus hereafter is on multinational partitions, executed by combinations of insiders and outsiders, that eventually result in new international borders, and which cut across historic homeland jurisdictions within union states or federations, and which divide citizens and subjects. The definitional discussion and throat-clearing is now over. It has an important consequence, which flows from the definition and discussions of types, and justifies this extensive prologue. In the 20th century, there were much fewer partitions than imagined by some, certainly fewer than the number of secessions, and the numbers of decolonizations. ${ }^{19}$ Executed partitions are, of course, much fewer than the number of proposed partitions. This makes the analysis of partitionist cases easier from the perspective of learning the relevant histories, and mastering the particular and rival explanations of specific partitions. For example, Sambanis identifies 125 civil wars since 1944, of which he classifies 21 as accompanied by partitions (by his definition). No one can master the historiography of 125 civil wars, and will be profoundly taxed when researching 21 case studies. But by my definition, by contrast, just four of Sambanis's cases can definitely be coded as multinational partitions: Azerbaijan/NagornoKarabakh (1988-1996); ${ }^{20}$ Cyprus (1974); ${ }^{21}$ India (1947-1948: including the partition of India, Bengal, Punjab, and of Kashmir in 1949); ${ }^{22}$ and Palestine (1947-1949). The former Yugoslav state of Bosnia-Herzegovina is a debatable case (Bose, 2002). Its external borders, within which it seceded from Yugoslavia, were restored intact at Dayton, but internally one of the two entities recognized, namely Republika Srpska, was the result of expulsions and partition, and in consequence so was its partner the Federation of Bosnia-Herzegovina. The partition

\footnotetext{
${ }^{19}$ All 20th century sovereign boundary changes must be investigated to confirm the truth of this assertion.

${ }^{20}$ This conflict (1988-1996) was a contested secession, within an existing administrative unit, involving reciprocal expulsion attempts by Azeris and Armenians, but it became a thus far (internationally unrecognized) partition because Armenia cut a fresh corridor across Azerbaijan to link Karabakh to Armenia.

${ }^{21}$ Sambanis counts the 1963 Cypriot communal conflicts, which led to internal expulsions and ethnic concentrations, as a partition. I do not, because no fresh sovereign - or indeed internal administrative-borders resulted.

22 The "unrecognized" line of control in Kashmir is a de facto partition of the Kashmiri national homeland.
} 
of India may, if one wishes to be broad-minded, be coded as four separate partitions (of Punjab, of Bengal, and later of Kashmir, as well as the partitioning of India from the two parts of Pakistan). ${ }^{23}$ However, we resolve these cases, we are left with a very small total number of cases (between five and eight). The small number of external partitions since World War II may reflect two features of international law: the taboo on territorial change by conquest (Zacher, 2001), and on partition by decolonizing powers after the bloodbaths between 1947 and 1949. External partitions, at least, have been taboo. One of the functions of this paper and its partner paper (O'Leary, 2007) is to maintain that they should stay that way.

\section{Explaining partition}

\section{The historical dimension}

Most explanations of partitions are indistinguishable from justifications - that is they explain the motives of the partitionists as the results of their ethical and practical beliefs, and these I examine separately (O'Leary, 2007). But general explanations of why partitions occur exist. One is an attempt at world-periodization. Robert Schaeffer differentiates 20th century partitions that (i) occurred as part of a process of decolonization (Ireland, India and Palestine); (ii) were the product of the cold war (Germany, Korea, Vietnam, China and Taiwan); (iii) were the product of a decisive neighborhood power (Turkey in Cyprus, and, I would add, in Kurdistan); and (iv) those that have taken place in more recent times as the byproduct of democratization processes in multinational states. He has in mind the former USSR, the former Czechoslovakia, the former Yugoslavia, and Ethiopia (Schaeffer, 1999: introduction; and see Schaeffer, 1990).

This is a classification with some merit. The distinction between decolonizing partitions and cold war partitions in the examples cited by Schaeffer is coterminous with my distinction between national partitions and multinational ones. But the partition of Cyprus partly flowed from the politics of its decolonization, and the treaties that accompanied it, so it cannot be entirely separated from the multinational or bi-national cases. However, the breakup of communist federations, which were occasioned by multiple secessions, should not, by my account, be treated as the same phenomena as partitions-even though some attempts at partition accompanied these secessions, notably in Bosnia-Herzegovina, and more successfully in the Armenian cutting of a land corridor to Nagorno-Karabakh.

Even if we counted partitionist attempts as flowing from the breakup of the communist federations, we must not forget that decolonization and the democratization of former multinational communist states had similarities. The USSR was an empire, and the Bolsheviks engaged in numerous gerrymanderings of the boundaries of Soviet republics. But Schaeffer's analysis, like Sambanis' considered earlier, leads to an exaggeration of the number of partitions affecting sovereign states that have been implemented in the 20th century. He opens one book with the statement that "partition is a common political practice" (Schaeffer, 1990: 1), claiming that since 1920, 13 countries have been divided, resulting in the creation of 37 successor states. These include Ireland, India, Palestine, Cyprus, Korea, Vietnam, Germany and China. But his remaining five cases, the breakups of Pakistan, Czechoslovakia, Ethiopia, the USSR

\footnotetext{
23 There was definitely a Bengali and Kashmiri national consciousness, but Punjab's collective identity was contested. The Congress party regarded - and so did its voters - all of British India as a nation, and thus construed partition as a partition of one nation, denying the thesis that India's Muslims were a nation.
} 
and Yugoslavia - which have produced the bulk of the successor states - are not partitions by my proposed coding. Pakistan was not partitioned by India in 1971: East Bengal's secession as Bangladesh was recognized, and enforced by India, with no border adjustments. Czechoslovakia and Eritrea/Ethiopia, as already observed, are examples of agreed secessions, not partitions. The USSR broke up through a series of agreed secessions led by the Baltic Republics and the Russian Federation - with only one partition, namely Armenia's cutting through of Azerbaijan. Yugoslavia's breakup, by contrast, is a story of multiple actual and contested secessions, and of several proposed and attempted partitions. Only the formations of the borders of Republika Srpska within Bosnia-Herzegovina are the result of the partial recognition of a partition conducted by self-styled liberationists who engaged in extensive expulsions and genocide.

Definitions therefore matter in counting the number of cases of partition, and their periodization and evaluation. If my opening analysis is accepted, fully fledged external partitions, especially of multinational polities have been rare, not common. There have been far more de-colonizations with colonial borders left intact; and far more secessions, both peaceful and violent, than there have been external partitions. If my proposed coding is accepted, this has decisive implications for evaluating trends. Because Schaeffer thinks that the post-communist breakups are examples of partitions, he concludes that we have seen a recent increase in the number of partitions, and that whereas partition used to be "what powerful states did to weak ones" today "partition is what weak states do to themselves" (Schaeffer, 1999: 7). My proposed coding, by contrast, suggests no such trend.

Partition remains something that powerful states may implement on the anatomies of weaker polities - as Serbia tried to do to Bosnia-Herzegovina. And proponents of partition may flourish when great powers intervene in multinational and pluralist states, as has happened recently in the Balkans and Iraq. But one can still maintain that partition's incidence has been minimal in the last 60 years because strong states uphold colonially established borders in Africa and Asia and because the right of conquest and prolonged occupation is illegal (Cassese, 1995). The fact is that it is easier to have a secession recognized (for example, in Croatia, Slovakia, Bosnia-Herzegovina, Macedonia, and the successor states of the USSR) than it is to have a partition recognized (for example, the Turkish Republic of Northern Cyprus, and Armenia's occupation of Azeri sovereign territory). The Irish Constitution has recently recognized the partition of Ireland, but only with provisions that enable it to be reversed. There may have been a recent increase in attempted partitions, and proposed partitions, but that is more difficult to determine. My suggestion would be that such proposals are more common in zones with partitionist pasts, or where polities are subject to interventions.

Schaeffer's periodization points in an appropriate direction in seeking to explain partitions. Democratization involves the definition of the people, and defining the people is the most intractable problem in democratic theory and practice. Externally proposed and imposed partitions of national and of multinational units occur where there is no agreement on who constitutes "the people". But that is not the end of the story.

\section{The role of great powers}

The great powers have shaped the world's borders. The greatest territorial empire in human history was British. Irish, Indian and Palestinian nationalists are especially tempted to think that partitions are peculiarly British. This perspective is articulated by Hitchens (2003), who offers a typically caustic and enlightening view of the political and literary legacy of partition. Ireland, Palestine and India fit the charge. One might add colonial Iraq, from which Kuwait was hived 
off as a quasi-protectorate before Iraq was granted its independence-whence the Ba'athist claim that it should be Iraq's "nineteenth governorate". British policymakers inclined towards "two-nations" and "two irreconcilable religions" arguments in Ireland, Palestine, and India. They had a prior history of "divide and rule" in all of these territories. When one removes "rule" from the formula, one is left with "divide". The British had a prior history of supporting - and being supported by-one minority (Ulster Unionists, Zionist Jews, Indian Muslims, Turkish Cypriots) against the emergent national majority. When one ceases to "divide and rule" one may "divide and quit", as Moon (2002 [1961]) famously charged was true of India, and was true of Palestine, but not Ireland.

The precedent set by Ireland - and perhaps some of the frontier adjustments of the League of Nations-encouraged some imperial elites to think of partition as a viable strategy in Palestine and India. Precisely because Ireland's partition was not as immediately (literally) bloody awful as its successors, it was widely coded until the 1960s as successful triage.

But, alas, one cannot solely hold British imperialists culpable for partitionist enthusiasm. Other empires were "internally" partitionist when they seized colonies or merged territories. Partitions have also been advocated in regions that were never inside the British Empire: in the Balkans (for example, in Bosnia and Kosovo); in the Caucasus (for example, Chechnya); in Africa (for example, Rwanda and Burundi); and in regions which have left the British Empire (for example, in the postcolonial Arab and Muslim world, in contemporary Iraq, and Afghanistan). But, significantly, partitions in these regions have not been (fully) executed, recognized, or (in some cases) even attempted. Cyprus does not neatly fit the hypothesis of British imperial culpability. Its partition occurred after decolonization, though a case might be made that the British failed to fulfill their treaty obligations when they did not stop the Turkish invasion in 1974. Palestine also does not fully fit the hypothesis. The Foreign Office and the Colonial Office were divided over the merits of partition. It was the United Nations, the USA and Abdullah of Transjordan, rather than the British, who provided the final external impetus for partition. In Ireland, the demand for the exclusion of (at least parts of) Ulster from home rule and Irish independence came from unionists in both Britain and Ireland. It was a metropolitan as well as a colonial question. Partition of Ireland was not a Liberal or a Labour enthusiasm; it was the Unionists in Lloyd George's coalition who drove it. Labour's leaders were not keen on the partition of Ireland (MacDonald), of Palestine (Bevin), or of India (Attlee, Cripps). Therefore, a generic British political disposition to partition cannot be generated from these histories, and the British did not partition all their other multi-ethnic or their bi-communal colonial territories, such as Sri Lanka, Sudan, and Malaysia. Perhaps by then they had learned that partitions do not work, at least not as intended.

Yet, other decolonizing empires-France, the Netherlands, Spain, Portugal, and the USSRdid not partition their colonial territories on their departures, so there is some merit to the idea of British distinctiveness. Proposals were made to partition Algeria, and to keep a French enclave, but these were rejected. Protecting territorial integrity and promoting linguistic assimilation within their colonial units meant that the French were arguably faithful to their Jacobin heritage. The Dutch, the Spaniards and the Portuguese were too enfeebled on exit from their colonies to implement partitions; both Spain and Portugal were so weak that they left Morocco and Indonesia, respectively, the opportunity to conquer "Spanish Sahara" and "East Timor". Remarkably, the Russian Federation resisted the calls of Alexander Solzhenitsyn and others to partition Kazakhstan, despite the proximity of Russian and Russian-speaking settlers to the border of the federation. So far, it has not contemplated partition in response to the contested secession of Chechnya. Whether this reflects a republican, anti-colonial or Soviet heritage 
might bear scrutiny. The United States, with the exception of its support for the formation of Israel, has not promoted partitions in its exercise of hegemony after $1945 .{ }^{24}$ It is "un-American" to read neoconservative and realist policy advocates sounding like their British predecessors when they discuss partitioning Bosnia, Kosovo, Afghanistan and Iraq.

\section{The role of nationalists and their communal opponents amid democratization}

One reason why there may have been a higher incidence of partition under or after British rule is that the British sometimes granted meaningful responsible and democratic government within their empire before they left. Ethno-national mobilization in Ireland occurred against a background of the widening of the franchise. Four-fifths of Ireland's voters had insisted upon home rule for four decades from the 1880s, but the descendants of colonial settlers, mostly concentrated in Ulster, opposed them, with the help of Great Britain's unreformed House of Lords (O'Leary \& McGarry, 2008: chap. 2). The issue at stake between them not only polarized Irish but also British politics, being the principal cleavage between the Liberals and the newly named Unionists (Conservatives and Liberal Unionists). The refusal of autonomy to Ireland eventually made a violent and democratic secessionist bid certain. Its materialization forced the British to downsize, but the presence of Unionists in Lloyd George's coalition ensured support for Ulster Unionist resistance. In India, nationalist and communal mobilization occurred against a widening of the franchise: the Congress party and the Muslim League were beneficiaries of increasing representative and responsible government at provincial level in India. In Palestine, Jewish settlers were internally democratically organized. In Cyprus, democratic mobilization occurred shortly before decolonization, and competitive pressures among Greek Cypriot politicians made it less likely that the 1960 accommodation with Turkish Cypriots would be maintained.

Implicit in this hypothesis is that democratization in conditions of potential multinationalism encouraged party formation on the basis of existing national, ethnic or communal cleavages, thereby making the conciliation of competing demands more difficult, and making the formation of "a common demos" problematic. Partition similarly came onto the policy agenda amid emergent democratization and rapid ethno-national mobilizations that accompanied the breakdown of communist dictatorships. But though this reasoning may explain why partition reached the policy agenda, it does not explain why it was chosen or implemented, or not.

Blaming ruthless and ambitious political entrepreneurs, intent on maximizing the likelihood of winning office or maintaining their leadership status, is a favored theme of historians and political scientists. Applications of this style of thought may be found in accounts for the drive toward executed partitions. The top-down or "high politics" school behooves us to analyse the elites who supported partition, and scrutinize the instrumental motives behind the conduct of politicians. Partition in much political historiography is seen as the byproduct of a multilayered bargaining game over power and resources between the pro-partition minority, the anti-partition majority and imperial or other third parties.

The minority leaders who sought partition in Ireland, Palestine, India and Cyprus are fascinating specimens: Carson and Craig, Weizmann and Ben-Gurion, Jinnah, and Denktash. None began as advocates of partition. No doubt, the same will be shown to be true of Bosnian Serbs

\footnotetext{
${ }^{24}$ Its cold war support for the mono-national partitions of Germany, Vietnam and Korea is, by contrast, a matter of record.
} 
and Serbian Serb leaders of the 1990s. Carson, the Dublin unionist, accepted home rule for Northern Ireland and Irish independence with deep reluctance; indeed, he regarded it as a failure. Craig, by contrast, thought a six-county Northern Ireland would be a new impregnable Pale from which to resist Irish nationalism. Both men were ruthless in advocating the abandonment of their co-unionists in counties Monaghan, Cavan and Donegal, the rest of the ancient province of Ulster. A secure majority, which Craig would hold until his death in 1940, was more important than securing as many unionists as possible. Mohammed Ali Jinnah, a Bombay Muslim, did not become an exponent of partition or of the two nation thesis until his 60s (Jalal, 1985). He had been an early, prominent and successful Congressman, and an advocate of secular politics - which he remained. His transformation remains debated. Among the favored suggestions are resentment at loss of salience during Gandhi's ascendancy; the unwinding of the Lucknow pact on separate electorates; opportunism after the electoral failure of the Muslim League in 1937; and the persuasiveness of Iqbal's arguments on two nations and the definition of Pakistan. Jinnah's past persuaded the Congress party and British officials that he was not a serious exponent of Pakistan, but was just bargaining on behalf of his own and Muslim interests. They saw him as a communal manipulator. They called his bluff. They found themselves in error-he was just bargaining as hard as he could to avoid a "moth-eaten Pakistan", which is what he got. Like Carson and Craig, he eventually recommended abandoning his supporters elsewhere-in the non-Muslim majority provinces. Weizmann and Ben-Gurion were prominent early Zionists, and definers of the prospective boundaries of "Eretz Israel". They became early "partitionists" (of mandate Palestine) because they thought it better to have a state than not to have one, and were willing to be ruthless in establishing such a state-whence BenGurion's interest in "transfers". They had King Abdullah as their equally calculating territorial colluder and collaborator across the Jordan (Shlaim, 1998).

So, hardline leaders, solidly endorsed by their most militant and insecure followers, themselves of settler colonial origin, or regarding themselves as of formerly dominant and superior origin-are all parts of the story in these four cases. But why did such leaders succeed? In Ireland, India and Cyprus, but less so in Palestine, revisionist historiography blames the respective nationalist leaders of the majority communities for placing other priorities ahead of national unity, or for failing to use their opportunities for more inclusive nation-building. Sinn Féin's leaders (Eamon de Valera, Michael Collins and Arthur Griffith) are held responsible for prioritizing sovereignty ahead of the integrity of the national territory. They made insufficient allowance for the identities, interests and ideas of their fellow Protestant Irishmen. They are collectively and individually criticized for mishandling the negotiations with Lloyd George's coalition government. They should have, as they had planned, made Ulster rather than the Crown, the break-issue in the negotiations. Congress' high command is similarly held culpable by some historians (Jalal, 1996). Nehru's underestimation of communalism, Patel's pandering to Hindu versions of it, and Gandhi's pervasively Hindu discourses are taken to task- to debunk Congress's secular self-representation. Congress' leaders placed the attainment of independence and a strong central government ahead of accommodating the identities, interests and ideas represented in the Muslim League, which it underestimated. Its failure to ensure that the Congress-run provinces accommodated the League after 1937 is much emphasized-it undermined Muslim support for an all-India state. In Cyprus, Archbishop Makarios is held culpable for seeking to unwind the generous settlement reached with Turkish Cypriots, though it is recognized that he risked being outflanked by ultra- and pro-enosis nationalists (as confirmed in the coup d'état that toppled him). (Little revisionist literature, by contrast, criticizes Palestinian leaders for insufficiently accommodating the interests of Zionists). 


\section{The balance of ethno-national forces}

These arguments are salutary reminders of the flaws of the respective nationalist leaders and movements, but they perhaps go too far in emphasizing their freedom of choice. They had constituencies. Irish and Indian independence had been long sought and blocked by British imperialists. Irish, Indian and Cypriot nationalism were all formally civic. They were not devoid of initiatives to compromise with their respective minorities. The first two showed willingness to compromise in key negotiations over future institutions-on a provincial parliament for Ulster within Ireland, on a loose federation for India- and the Greek Cypriots agreed remarkably generous consociational terms for Turkish Cypriots in 1960. The respective elites certainly mattered, but what, we might ask, of their publics? What responsibilities for partitions lie with mass public sentiments and activities?

What of the view that partition is driven by irreconcilable collective identity differences, emanating from long-established hatreds (or recently established hatreds), inflamed by religious differences, and its corollary, that democratization, decolonization, and the prospect of a new political order, after imperial or dictatorial rule, bring such passions to the fore? It will not do simply to burn these theses as the ravings of that favored beast of the social science jungle, the "primordialist". Such ridiculing is laughter at the expense of much of the non-academic sections of the human species. ${ }^{25}$ Cosmopolitans in our times insist that our identities are flexible, multiple, open, fluid, unpredictable and not driven by inherited traditions. They tend to deny that ethno-national conflicts are ever rooted in ancient hatreds or recent history.

This is not the place for a general treatment of facile arguments, but we should not confuse necessary and sufficient conditions. It may be necessary for serious ethno-national conflict to occur that politicians, paramilitaries and others, make claims about historic maltreatment of their peoples, and warn of future insecurities. But it is essential that these claims have some resonance, some credibility, with the targeted publics if they are to have any impact. Ethnonational grievances and religious communalism had prior histories in Ireland and India before democratization. Zionism, secular or otherwise, was a response to Jewish collective grievances, mostly at the hands of European rulers, and magnified exponentially by the Holocaust. Cypriots were divided by language, religion, and political identification. It would be foolish to deny histories of international, interethnic and cross-religious cooperation within places that subsequently become the site of partitions. But it equally makes no sense to deny that collective identities and sentiments, and their communal expressions in hostile, negative and stereotypical forms, provided fertile grounds for political mobilizations and counter-mobilizations. But they do not, whatever view we take on their rigidity or longevity, suffice to explain partitions, except, perhaps, in accounting for the motivations of the partitionist.

\section{The politics of partition}

Partition, ultimately, is a political decision, determined by imperial or external state parties, who believe in irreconcilable differences between local parties, and who believe that the relevant protagonists are engaged in a self-fulfilling primordial struggle, and decide to determine a final settlement (in conditions of democratization and/or decolonization) rather than allowing

\footnotetext{
${ }^{25}$ Francisco Gil-White $(1999,2001)$ points out that while academics may be uniformly anti-primordialist the same is not true of most non-academics, who generally matter more.
} 
the local agents to be decisive. They implement such partitions, during or after wars, when downsizing, or decolonizing, or, perhaps, in future, after humanitarian wars of intervention. This thesis caps the story. Partition needs partitionist agents, as well as collaborators. The agents need to be appropriately motivated.

The aftermath of World Wars I and II weakened Britain's power in Ireland in the first case, and in India and Palestine in the second. The coming ascendancy of the USA and the doctrines of national self-determination propagated by the new American and Soviet great powers made the maintenance of empire abroad and the denial of Irish autonomy at home no longer such credible commitments-except for the imperial diehards. In these three cases, British politicians sought a settlement in which they could protect their interests as best they could-with Ireland's sovereignty circumscribed by Britain's defense interests, and with geopolitical considerations in India and the Middle East. In the post-World War II cases, the British quit, with a speedily managed partition in one case, in the other by handing over the decision to the United Nations. For the first and the last time in its history (to date), the United Nations proposed a partition, the details of which were later rendered irrelevant by war, and whose consequences still haunt the region. Turkey invaded and partitioned Cyprus to pre-empt a Greek takeover of the island, at a time when Turkey was undergoing a periodic democratization and Greece was under military dictators. The Greek Cypriot exponents of enosis and the Greek dictators gave the Turks their casus belli. But Turkey still faces the problem that its partitionist settlement, apart from its gross unfairness, and over-indulgence of its co-ethnics, in land share, is not internationally recognized.

This last case may function as a final thought in explaining partitions in the 20th century. Partition ceased to be an internationally approved instrument of sovereign, or great, powers. It ceased to be as thinkable and condonable as it once was. We live in a world in which wars of conquest, and recent imperial conquests are formally morally and legally repudiated. This has been so since the United Nations formulated new codes and practices-and has been reinforced as the United Nations expanded with numerous new republics (Cassese, 1995).

Think of the point this way. Had the United Nations been handed the Palestine mandate in 1960, it is likely that it would have recommended the formation of a bi-national state, rather than a partition (reversing the rankings of its majority and minority reports in 1947). It has become a taboo for external powers to redraw lines on the map as they see fit, just as it is no longer acceptable for some imperial people to rule others. That is why Israel's conduct in the West Bank and Gaza has occasioned such widespread criticism. (While its recent decision to quit Gaza has been welcomed, its declaration of intent unilaterally to redraw the boundary of the West Bank has been almost universally condemned outside Israel). That is why neither the EU nor the USA could bring themselves to play the role of formal partitionists in Bosnia. When there is nominal equality between states and peoples, to propose partition is to propose that it be executed by paternalistic partitionists-which requires an imperial hegemon, or the United Nations. The most likely hegemon, the USA, has resisted calls for it to act as a partitionist, in Bosnia, Kosovo- and indeed, to date, in Iraq. If Iraq breaks up, it will do so around its recognized regions and governorates, that is, through secessions. Only conquests by its neighbors would lead to an external partition. The Kurdistan Region is recognized in the 2005 constitution; other regions may now be formed after 2008 under a statute passed in 2006. But it is possible to argue that any partitions that occur in Iraq will be the outcome of internal civil wars, between Sunni and Shi'a Arabs, or between Arabs and Kurds.

In short, the United Nations and other international regional organizations may expect to be given the task, now and in the future, with managing international protectorates, and 
supervising complex consociations, for example, in Bosnia and Macedonia. They may be required to supervise secessionist referendums, for example, in Kosovo. But they are not likely to be granted, nor should they be empowered with the rights and tasks of a partitionist. No one can credibly claim to have the required wisdom or power to be the world's Solomon.

\section{The reversibility of partitions}

Two last questions are important in appraising partitions. One is empirical; the other is political. The empirical issue is whether they are reversible. The political question is whether they should be reversed. Partitions are certainly reversible in principle, just as annexations and conquests are reversible. In the last century, China reversed the European imperialists' partitions of its territory. The partitions of nations have been reversed in our times: Germany and Vietnam have demonstrated this by consent, and by conquest and consent, respectively. It is a safe bet to predict the eventual overturning of mono-national partitions. Korea's unification may not be too far away, and South Korea at least is partly prepared. By contrast, no safe prediction can be made with regard to the reversal of the partitions of multinational territories. Neither a Greater Hungary nor a Greater Romania appear likely. There are, however, places where people are intent on reversing partitions. The ambitions of some Irish, Palestinian and Greek Cypriot nationalists are plain; by contrast, few Indian nationalists advocate reunification with Pakistan, and the political weakness of pan-Bengali nationalism must be coded one of the key surprises of modern politics. In five of the cases we have considered in some depth, there remain vigorous champions of the original partition among their presumed beneficiaries: Ulster Unionists, Pakistanis, Israelis, and Turkish Cypriots, and, if we code Bosnia-Herzegovina as a partial partition, the same holds for Bosnian Serbs. The partition of historic Kurdistan has four regional agents in favor of its continuation: the governments of Turkey, Syria, Iran and most Arab political opinion in Iraq. Reversing that partition in full is not the operational goal of Kurdistan in Iraq's most successful political parties. Kurds wish to reverse the partition of the Kurdistan region within Iraq, but for now within a federal Iraq rather than outside it (O'Leary, McGarry, \& Salih, 2005). That limited goal is feasible.

Two brute factors are likely to determine the viability of reversing a partition: demography and geopolitics. If an orphaned minority becomes a majority in the successor entity of its rival, it may then be able to champion reunification. This scenario may materialize in Northern Ireland in this century. Its mere possibility is widely held to explain some of the greater reasonableness about power-sharing and consociation among Ulster Unionists. If Cyprus' accession to the EU is accompanied by full freedom of movement on the island, it is not likely that the Turkish Cypriot entity can be upheld as one in which that community (or that community of communities) can remain a majority. Likewise, if local and global power-holders change, or shift their dispositions, this may facilitate the reversing of a partition. The United Kingdom is no longer a global imperial power; it is also no longer a strongly unitarist unionist state at home; it is a European power; and joint membership of the European Union means that the UK and Ireland find it easier to cooperate in overseeing a complex consociational settlement. They may one day cooperate in organizing a change in Northern Ireland's sovereign status, as their respective treaty and legal obligations require them to do if there are majorities in favor in both units in Ireland.

Until now, in Cyprus and Israel, by contrast, the beneficiaries of partition have consistently been able to follow demographic policies of immigration, or of settler-infusion, and of rigorous control over the orphaned minorities, policies intended to inhibit the feasibility of reversing the 
original partitions. In Israel's case, these policies seem viable behind the borders established after 1948; they do not seem viable in all of historic Palestine; and the borders may be renegotiated, as Israel's leaders appear willing to consider, if only through unilateral down-sizing. The Turkish Cypriots are geopolitically weaker than the Israelis. Greece and Greek Cyprus have a veto on Turkey's accession to the EU; Turkey, to date, wants to join that Union. A cosponsored federal and consociational reunited Cyprus is within the feasible set of options for all three states. The United Nations proposed just such a settlement, but it was too generous for Turkish Cypriots to win the assent of their Greek Cypriot counterparts; any new settlement will have to be crafted as part of Turkey's complex accession. By contrast, Israel is not so constrained, so far, by the interests of US foreign policymakers. In short, Ireland and Cyprus are the most likely possibilities for the full reversal of partitions of multinational territories, while Palestine and India/Pakistan are the least likely. But even if reversal happens in either Ireland or Cyprus, such changes will need to be accompanied by external state sponsorship and consociational pacts to reduce existential and other threats to the security and identity of the losers. The reversal of the status of Republika Srpska will require both the willing and supported return of its exiled minorities and the weakening of at least the federal dimensions of the constitution of Bosnia-Herzegovina.

Analysis is one thing; moral evaluation and prescription for the future are different. Here I wish to emphasize that just because one should generally oppose proposed partitions, one need not necessarily support all efforts to reverse partitions that have been executed. The practical feasibility of overturning a partition does not mean that that is the best political option for the affected peoples. The reunification of Ireland and of Cyprus under confederal and consociational formulae may be in the material and collective interests of all the majorities of the affected peoples. By contrast, reunification in either the Middle East or South Asia is less obviously in the interests of the affected peoples. It is possible to argue that the partition of Palestine was wrong, and should not have happened, but to maintain that the full reversal of that partition would create more difficulties than it would resolve. Champions of a two-state solution to the Israeli and Palestinian conflict may be right to argue that a bi-national state would not work after all that has transpired. It is also possible to argue that the partition of the Indian subcontinent was wrong, and should not have happened, but to oppose a full political reunification of the subcontinent and instead to favor softer forms of association, such as a South Asian Common Market, and to encourage a settlement in Kashmir which has the assent of its peoples.

\section{Conclusion}

For those who are not historicists, there can be no certainty that there will be no further external partitions. But this paper's determined effort to distinguish partition from secession suggests that external partitions are rare (internal partitions to control particular ethnic communities are much less rare, but that is another subject). Moreover, I can claim on the basis of arguments developed at greater length elsewhere that anti-partitionists have better arguments, judged by realistic, democratic and moral criteria (O'Leary, 2007). External partitions have not generated better security environments. Most partitions have been biased towards privileged or dominant minorities. Partition and post-partition arrangements have been worse than those predicted by supporters of partition for at least one successor unit. Partitions have always caused more violence during and after the partition than occurred before the partition. Partition's apologists are invariably obliged to argue that the pathologies that accompanied their proposed partition were the result of an imperfect design, or of insufficient rigor and resolution. 
This response is typically unfalsifiable and unconvincing. Prudence mandates opposing partition as a tool of international public policy-making, and placing the burden of proof on its advocates. Of course, it cannot be known for certain in advance that there will never be any cases where partition truly is a better policy option than the alternatives, but the standard for making that argument should pass a very high threshold, namely that partition is demonstrably the best way to prevent genocide, or its recurrence (O'Leary, 2007).

\section{Acknowledgements}

The author would like to thank attendees at conferences in South Bend, Indiana in December 2001, and in Armagh in January 2006, for their constructive and critical engagements with previous versions of this text. He would also like to thank John Coakley, Tom Lyne, Ian S. Lustick, John McGarry, John O'Loughlin, and the three anonymous reviewers, especially the one who suggested publication without changes.

\section{References}

Bose, S. (2002). Bosnia after Dayton: Nationalist partition and international intervention. New York: Oxford University Press.

Brubaker, R. (1996). National minorities, nationalizing states, and external national homelands in the New Europe. In: Nationalism reframed: Nationhood and the national question in the New Europe (pp. 55-76). Cambridge: Cambridge University Press.

Cassese, A. (1995). The self-determination of peoples: A legal reappraisal. Cambridge: Cambridge University Press.

Chatterji, J. (1999). The making of a borderline: the Radcliffe award for Bengal. In I. Talbot, \& G. Singh (Eds.), Region and partition: Bengal, Punjab and the partition of the subcontinent (pp. 168-202). Karachi: Oxford University Press.

Connolly, J. (1975). Ireland upon the dissecting table: James Connolly on Ulster and partition (New ed.). Cork: Cork Workers Club.

Connor, W. (1986). The impact of homelands upon diasporas. In G. Sheffer (Ed.), Modern diasporas in international politics (pp. 16-46). London: Croom Helm.

Conras, V. (1975). Self-determination and the partition of states in international law. Cambridge, MA: Harvard Law School.

Drysdale, J. (2000). Stoics without pillows: A way forward for the Somalilands. London: HAAN Associates Publishing.

Esman, M. (1985). Two dimensions of ethnic politics: defence of homelands, immigrant rights. Ethnic and Racial Studies, 8, 438-441.

Gellner, E. A. (1979). Words and things (2nd ed.). London: Routledge and Kegan Paul.

Gil-White, F. J. (1999). How thick is blood? The plot thickens: if ethnic actors are primordialists, what remains of the circumstantialist/primordialist controversy? Ethnic and racial studies, 22, 789-820.

Gil-White, F. J. (2001). Are ethnic groups biological 'species' to the human brain? Essentialism in our cognition of some social categories. Current anthropology, 42, 515-555.

Henderson, G., \& Lebow, R. N. (1974). Conclusions. In G. Henderson, R. N. Lebow, \& J. G. Stoessinger (Eds.), Divided nations in a divided world (pp. 433-456). New York: D McKay.

Heraclides, A. (1991). The self-determination of minorities in international politics. London: Frank Cass.

Hitchens, C. (2003). The perils of partition. Atlantic monthly, March, 99-107.

Hoare, A. (1997). The Croatian project to partition Bosnia-Herzegovina, 1990-1994. East European quarterly, 31, $121-138$.

Horowitz, D. (1985). Ethnic groups in conflict. Berkeley, CA: University of California Press.

Indian National Congress. (1947). The memorandum on the partition of Bengal presented on behalf of the Indian National Congress: case before the Bengal boundary commission, Calcutta, 1947, in AICC-I C. 14 (D)/1946.

Innes, A. (2001). Czechoslovakia: The short goodbye. New Haven: Yale University Press. 
Jalal, A. (1985). The sole spokesman: Jinnah, the Muslim League and the demand for Pakistan. Cambridge: Cambridge University Press.

Jalal, A. (1996). Secularists, subalterns and the stigma of 'communalism': partition historiography revisited. Indian Economic and Social History Review, 33(1), 93-103.

Kaplan, H. H. (1972). The first partition of Poland. New York: AMS Press.

Kaufmann, C. (1996a). Possible and impossible solutions to ethnic civil wars. International Security, 20, $136-175$.

Kaufmann, C. (1996b). Intervention in ethnic and ideological civil cars: why one can be done and the other can't. Security Studies, 6, 62-100.

Kaufmann, C. (1998). When all else fails: ethnic population transfers and partitions in the twentieth century. International Security, 23, 120-156.

Lake, D., \& Rothchild, D. (1998). Spreading fear: the genesis of transnational ethnic conflict. In D. Lake, \& D. Rothchild (Eds.), The international spread of ethnic conflict: Fear, diffusion, and escalation (pp. 3-32). Princeton: Princeton University Press.

Lindgren, R. E. (1959). Norway-Sweden: Union, disunion, and Scandinavian integration. Princeton: Princeton University Press.

Lukowski, J. (1998). The partitions of Poland: 1772, 1793, 1795. New York: Addison Wesley Longman.

McGarry, J., \& O’Leary, B. (1995). Explaining Northern Ireland: Broken images. Oxford: Basil Blackwell.

McGarry, J., \& O'Leary, B. (1993). Introduction: the macro-political regulation of ethnic conflict. In J. McGarry, \& B. O'Leary (Eds.), The politics of ethnic conflict regulation (pp. 1-47). London: Routledge.

Mansergh, N. (1997). The prelude to partition: concepts and aims in India and Ireland. In D. Mansergh (Ed.), Nationalism and independence: Selected Irish papers (pp. 32-63). Cork: Cork University Press.

Moon, P. (2002 [1961, 1982]). Divide and quit: an eyewitness account of the partition of India. In M. Hasan (Ed.), The partition omnibus (pp. 272-324). New Delhi: Oxford University Press.

O’Leary, B. (2001). Elements of right-sizing and right-peopling the state. In B. O'Leary, I. S. Lustick, \& T. Callaghy (Eds.), Right-sizing the state: The politics of moving borders (pp. 15-73). Oxford: Oxford University Press.

O’Leary, B. (2007). Debating partition: justifications, critiques and evaluation, Working Paper in British-Irish Studies Number 78, Institute of British Irish Studies, UCD-QUB, Dublin Belfast. Available from: http://www.qub.ac.uk/ cibr/WPpdffiles/MFWPpdf/w28_bol.pdf.

O’Leary, B., \& McGarry, J. (1995). Regulating nations and ethnic communities. In A. Breton, G. Galeotti, P. Salmon, \& R. Wintrobe (Eds.), Nationalism and rationality (pp. 245-289). Cambridge: Cambridge University Press.

O’Leary, B, and McGarry, J. (in press). Understanding Northern Ireland: Colonialism, control and consociation. London and New York: Routledge.

O'Leary, B., McGarry, J., \& Salih, K. (Eds.). (2005). The future of Kurdistan in Iraq. Philadelphia: University of Pennsylvania Press.

Rousseau, J. J. (1985 [1770]). The government of Poland, translated, with an introduction and notes by Willmoore Kendall. Indianapolis, IN: Hackett Publishing Company.

Sambanis, N. (2000). Partition as a solution to ethnic war: an empirical critique of the theoretical literature. World Politics, 52, 437-483.

Schaeffer, R. K. (1990). Warpaths: The politics of partition. New York: Hill and Wang.

Schaeffer, R. K. (1999). Severed states: Dilemmas of democracy in a divided world. New York: Rowman \& Littlefield.

Scruton, R. (1982). A dictionary of political thought. London: Macmillan.

Shlaim, A. (1998). The politics of partition: King Abdullah, the Zionists, and Palestine, 1921-1951. New York: Oxford University Press.

Taylor, P. J. (1993). Political geography: World-economy, nation-state and locality (3rd ed.). London: Longman.

Tolz, V. (1998). Conflicting 'homeland myths' and nation-state building in postcommunist Russia. Slavic Review, 57, 267-294.

Voltaire, F-M. A. de (1999 [1764]). Homeland, in the philosophical dictionary. In D. Williams (Ed.), The enlightenment (pp. 177-180). Cambridge: Cambridge University Press.

Waterman, S. (1984). Partition—a problem in political geography. In P. J. Taylor, \& J. House (Eds.), Political geography: Present advances and future directions (pp. 98-116). London: Croom Helm.

Waterman, S. (1987). Partitioned states. Political Geography Quarterly, 6, 151-170.

Yiftachel, O. (2001). The homeland and nationalism. In A. Motyl (Ed.), Encyclopaedia of nationalism (pp. 359-383). New York: Academic Press.

Young, R. A. (1994). How do peaceful secessions happen? Canadian Journal of Political Science, 27, $773-794$.

Zacher, M. W. (2001). The territorial integrity norm: international boundaries and the use of force. International Organization, 55, 215-250. 